\title{
Effect of Nitrogen and Phosphorus Level on Dry Matter Yield at Different Growth Stages of Popcorn in South Saurashtra Region of Gujarat, India
}

\author{
Shalini Kumari* \\ Department of Soil Science and Agricultural Chemistry, Junagadh Agricultural University, \\ Junagadh-362001, Gujarat, India \\ *Corresponding author
}

\section{A B S T R A C T}

Keywords

Nitrogen, Phosphorus,

Dry matter and Popcorn.

Article Info

Accepted:

04 June 2017

Available Online:

10 August 2017
A field experiment was conducted during rabi season of 2013-14 on calcareous soil under Saurashtra region. The experiment consisted of four levels of nitrogen $\left(0,90,120,150 \mathrm{Kg} \mathrm{N} \mathrm{ha}^{-1}\right)$ and four levels of phosphorus $\left(0,45,60,75 \mathrm{Kg} \mathrm{P}_{2} \mathrm{O}_{5} \mathrm{ha}^{-1}\right)$ making sixteen treatment combinations tested in factorial randomized block design with three replications. The results indicated that application of $150 \mathrm{Kg} \mathrm{N}^{-1}$ and $75 \mathrm{Kg} \mathrm{P}_{2} \mathrm{O}_{5} \mathrm{ha}^{-1}$ significantly increased the dry matter at 30DAS, 60DAS and at harvest of different stages of plant parts of Popcorn. The overall results indicated that combined application of nitrogen shows the synergistic effect on growth attributes of popcorn and sustain the yield.

\section{Introduction}

In Indian agriculture, maize assumes a special significance on account of its utilization as food, feed and fodder besides several industrial uses. According to latest data (2012-13), it is being cultivated on 8.49 million hectares with $80 \%$ area during kharifseason. Nowadays, the maize corn used for popcorn, is profitable for a lot of producers and traders. Maize production is 21.28 million tonnes, with an average productivity of $2.5 \mathrm{t} \mathrm{ha}^{-1}$ (NIIR, 2013). The current maize is grown on 9.3 million hectares with production of 24.2 million tonnes and productivity of $2602 \mathrm{~kg} \mathrm{ha}^{-1}$ in the country (FAO STAT, 2014). Despite maize being predominantly rainfed crop its productivity is more than rice which is mainly grown under assured irrigated/rainfed conditions. Maize contributes nearly $9 \%$ in the national food basket and more than 400 billion to the agricultural GDP at current prices. In Gujarat, the important districts growing maize are Dahod, Panchmahal, Vadodara, Sabarkantha, Kheda, Banaskantha, Bharuch, Anand and Dang.

The area under maize in the Saurashtra region is almost negligible. It is mainly cultivated in kharif season, and due to photo insensitive crop, it is also grown as rabi and summer crop. The maize is classified into seven principal groups on the basis of endosperm and floral bract or glume character viz., pod corn, popcorn, flint corn, dent corn, soft corn, 
sweet corn and waxy corn (http://www.itis.gov). Popcorn is very popular snack food in many parts of the world. The use of popcorn confectionaries and popcorn products especially in amusement parks, moving picture theaters etc greatly increased the demand for popcorn products and have made a profitable outlet for those who desire to grow popcorn on a commercial scale.

Nitrogen and phosphorus consumption has a strange effect on production of popcorn and expanding leaf area plants which receive the most nitrogen and phosphorus contain more leaf area index than wild plants. Maize is an exhaustive crop and requires high quantities of nitrogen during the period of efficient utilization, particularly at 25 days after sowing and pre-tasseling (40 days after sowing) stages for higher productivity. Nitrogen and Phosphorus are the two most essential nutrients in popcorn. Others nutrients that are limiting in soil and require fertilization for popcorn are $\mathrm{K}, \mathrm{S}, \mathrm{Zn}, \mathrm{Fe}$, etc. To produce one tone of grain and dry matter, maize crop withdraws $8.0 \mathrm{~kg}$ of $\mathrm{N}, 2.5 \mathrm{~kg}$ of $\mathrm{P}_{2} \mathrm{O}_{5}$ and $18 \mathrm{~kg}$ of $\mathrm{K}_{2} \mathrm{O}$ from the soil.

\section{Materials and Methods}

A field experiment was conducted during rabi season of 2013-14 at Instructional Farm, Department of Agronomy, College of Agriculture, Junagadh Agricultural University, Junagadh. The soil was clayey texture and slightly alkaline in reaction with $\mathrm{pH} 8.0$ and EC $0.27 \mathrm{dS} \mathrm{m}^{-1}$.

The soil was medium in available nitrogen (260.34 $\mathrm{kg} \mathrm{ha}^{-1}$ ), medium in alkaline in reaction with $\mathrm{pH} 8.0$ and $\mathrm{EC} 0.27 \mathrm{dS} \mathrm{m}^{-1}$. The soil was medium in available nitrogen (260.34 $\mathrm{kg} \mathrm{ha}^{-1}$ ), medium in available phosphorus (42 $\mathrm{kg} \mathrm{ha}^{-1}$ ) and medium in available potash (238 $\mathrm{kg} \mathrm{ha}^{-1}$ ) and low in available sulphur about of $\left(12 \mathrm{~kg} \mathrm{ha}^{-1}\right)$. The crop was fertilized with nitrogen and phosphorus as per treatment allotted to each plot. The nutrient levels were four levels of $\mathrm{N}\left(0,90,120,150 \mathrm{Kg} \mathrm{N}^{-1}\right)$ and four levels of phosphorus $(0,45,60,75$ $\mathrm{Kg} \quad \mathrm{P}_{2} \mathrm{O}_{5} \mathrm{ha}^{-1}$ ) and totally 16 different treatment combinations were laid out. The calculated quantity of entire dose of phosphorus and half dose of nitrogen were applied as basal application in the form of Urea and SSP at just before sowing in the furrows. Remaining half dose of nitrogen were top dressed in two splits as urea at 20 and 40 DAS, whereas sulphur supplied through SSP was equalized by cosavet fertiWG $(90 \% \mathrm{~S})$. All other cultural and plant protection measures were followed as recommended.

The popcorn variety Amber was used for this study. This variety was released in 1981 by SVRC, suitable for kharif and rabi season growing under irrigated conditions. The seeds were dibbled at a spacing of $60 \mathrm{~cm} \mathrm{x} 20 \mathrm{~cm}$ using a seed rate of $15 \mathrm{~kg} \mathrm{ha}^{-1}$ during the last week of November 2013. The data collected from experiment at different crop growth stages, yield, yield attributes, quality and chemical study were subjected to statistical analysis followed for Randomized Block Design in factorial nature as denoted by Panse and Sukhatme (1985).

Five plants per plot were selected randomly in the net plot are and tagged for observations at critical stages (30 DAS, 60 DAS and at harvest) for recording growth and yield parameters. Destructive sampling was followed to record dry weight at different stages.

The five randomly collected plants were dried at room temperature for two days and then oven dried at $65^{\circ} \mathrm{C}$ till a constant weight was obtained. The oven dry weight was recorded for estimating the dry matter yield in $\left(\mathrm{g}\right.$ plant $\left.{ }^{-1}\right)$. 


\section{Results and Discussion}

\section{Effect of nitrogen on dry matter yield at different growth stage}

The dry weight of leaves, stem, root, grain and total plant was significantly influenced by the different levels of nitrogen (Table 1 and Fig. 1). The dry weight of leaves, stem, root and total plant was recorded significantly higher with $150 \mathrm{~kg} \mathrm{~N}^{-1}\left(\mathrm{~N}_{3}\right)$ with values of 4.983, 16.565, 3.170 and $24.718 \mathrm{~g} \mathrm{plant}^{-1}$ respectively of popcorn at 30 DAS. The dry weight of leaves, stem, root and total plant was significantly influenced by the different levels of nitrogen. The dry weight of leaves, stem, root and total plant were recorded significantly higher with application of nitrogen@150 kg N ha ${ }^{-1}\left(\mathrm{~N}_{3}\right)$ with values of 20.26, 26.61, 5.18, and 52.30 g plant ${ }^{-1}$, respectively. It was also remained at par with application of $120 \mathrm{~kg} \mathrm{~N} \mathrm{ha}{ }^{-1}\left(\mathrm{~N}_{2}\right)$ for dry weight of leaves (18.84 $\left.\mathrm{g} \mathrm{plant}^{-1}\right)$ and stem $\left(25.45 \mathrm{~g} \mathrm{plant}^{-1}\right)$.The dry weight of leaves, stem, root and total plant (Fig. 1) at harvest were significantly affected by different nitrogen level on popcorn which was recorded higher with application of nitrogen @ $150 \mathrm{~kg}$ $\mathrm{N} \mathrm{ha}^{-1}\left(\mathrm{~N}_{3}\right)$ in value of $26.29,30.86,9.43$, 62,33 and $130.51 \mathrm{~g} \mathrm{plant}^{-1}$ respectively at 60 DAS (Table 1). It was also remained at par with $120 \mathrm{~kg} \mathrm{~N} \mathrm{ha}^{-1}\left(\mathrm{~N}_{2}\right)$ for dry weight of leaves $\left(24.53 \mathrm{~g} \mathrm{plant}^{-1}\right)$ only.

The dry matter accumulation rate by virtue of increased photosynthetic efficiency can be explained by the fact that the supply of nitrogen enhances the production of leaves, stem small roots and root hairs, which in turn facilitated the high absorbing capacity per unit dry weight. $\mathrm{N}$ uptake by maize fodder in response to nitrogen application was in close bearing with the response of total plant dry matter to $\mathrm{N}$ nutrient as had recently been reported by (Hussaini et al., 2001). Increased dry matter production with increased fertilizer application was due to role of nitrogen in determining the efficiency of sunshine by the increased biomass and any inadequacy of nitrogen reduces the sunshine use efficiency or ability to photosynthesize as reported by (Wadsworth, 2002). Thus greater availability of photosynthates, metabolites and nutrients to develop reproductive structures seems to have resulted in increased dry weight of vegetative parts of plants i.e., leaves, stem, root and grain. Initially, leaves rather than the number is increases but the number of leaves are subsequently increased by sustained leaf production over a longer period. Total dry matter production of sweet corn increased with increasing levels of nitrogen at all growth stages of crop observed by Kumar (2007). Such result clarified that $N$ is essential for cell division and elongation as well as the root growth and dry matter yield of maize plants, Marschner (1995). The application of nitrogen was found to increase the leaves dry weight of maize which may be due to selective and adequate nitrogen uptake in plant tissue. The leaves dry weight was significantly obtained from application of higher dose of nitrogen $180 \mathrm{~kg} \mathrm{ha}^{-1}$ (Hokmalipour and Darbandi, 2011). Singh (2001) reported that in baby corn, increasing nitrogen levels recorded significant increase in dry matter production in maize up to 150 $\mathrm{kg} \mathrm{N} \mathrm{ha}{ }^{-1}$ both in kharif and summer seasons. Total dry matter production was found significantly higher by maximum application of nitrogen (125 kg ha ${ }^{-1}$ in popcorn, (Kanannavar, 2013). The total dry matter production per plant differed significantly due to nitrogen levels. Every increase in nitrogen level from 75 to $225 \mathrm{~kg} \mathrm{ha}^{-1}$ increased the dry matter production from 266 to 323 g plant $^{-1}$ (Setty, 1981) in maize. Similar result was reported by Choudhary and Singh (2006), Hokmalipour et al., (2010), Babak et al., (2012) and Chabi et al., (2008), Verma and Singh (2014), Kumar (2009) in popcorn. 
Effect of phosphorus on dry matter yield at different growth stage

The data furnished in table 2 and figure 4.2.5 indicated that phosphorus applications at various levels significantly influenced the dry weight of leaves (20.24 g plant $\left.{ }^{-1}\right)$, stem (26.35 $\left.\mathrm{g}_{\text {plant }}{ }^{-1}\right)$, root $\left(5.01 \mathrm{~g} \mathrm{plant}^{-1}\right)$ and total plant $\left(51.61 \mathrm{~g} \mathrm{plant}^{-1}\right)$ which were recorded higher under applications of phosphorus @ $75 \mathrm{~kg} \mathrm{ha}^{-1}$ $\left(\mathrm{P}_{3}\right)$. Which were statistically at par with 60 $\mathrm{P}_{2} \mathrm{O}_{5} \mathrm{~kg} \mathrm{ha}^{-1}\left(\mathrm{P}_{2}\right)$ in leaves (18.91 $\left.\mathrm{g} \mathrm{plant}^{-1}\right)$ at 60 DAS. The interaction effect of nitrogen and phosphorus was found non-significant in terms of dry weight of leaves, stem, root and total plant of popcorn at $60 \mathrm{DAS}$. The data furnished in (Table 1 and Fig. 1b) indicated that phosphorus applications at various levels significantly influenced the dry weight of leaves (4.616 $\left.\mathrm{g} \mathrm{plant}^{-1}\right)$, stem (15.465 $\left.\mathrm{g} \mathrm{plant}^{-1}\right)$, root (3.038 $\left.\mathrm{g} \mathrm{plant}^{-1}\right)$ and total plant $(23.118 \mathrm{~g}$ plant $^{-1}$ ) which were recorded higher under applications of phosphorus @ $75 \mathrm{~kg} \mathrm{P}_{2} \mathrm{O}_{5} \mathrm{ha}^{-1}$ $\left(\mathrm{P}_{3}\right)$. It was found statistically at par with 60 kg $\mathrm{P}_{2} \mathrm{O}_{5}$ ha $^{-1}\left(\mathrm{P}_{2}\right)$ for leaves (4.501 $\mathrm{g} \mathrm{plant}^{-1}$ ), root (2.795 $\left.\mathrm{g} \mathrm{plant}^{-1}\right)$ and total plant $(22.499 \mathrm{~g}$ plant $\left.^{-1}\right)$, while $45 \mathrm{~kg} \mathrm{P}_{2} \mathrm{O}_{5} \mathrm{ha}^{-1}\left(\mathrm{P}_{1}\right)$ and $60 \mathrm{~kg}$ $\mathrm{P} \mathrm{ha}^{-1}\left(\mathrm{P}_{2}\right)$ for stem with value of 14.939 and $15.203 \mathrm{~g} \mathrm{plant}^{-1}$ at 30 DAS. The interaction effect of nitrogen and phosphorus was found non-significant in terms of dry weight of leaves, stem, root and total plant of popcorn at 30 DAS. Increased dry matter production with increased fertilizer application was due to role of NPK in determining the use efficiency of sunshine by the increased biomass and any inadequacy of nitrogen reduces the sunshine use efficiency or ability to photosynthesis as reported by Wadsworth (2002), Chabi et al., (2008), Verma and Singh (2014), Kumar (2009) in popcorn.

Table.1 Effect of nitrogen and phosphorus on dry matter at 30 DAS,

60 DAS and at harvest of popcorn

\begin{tabular}{|c|c|c|c|c|c|c|c|c|c|c|}
\hline \multirow{2}{*}{ Treatments } & \multicolumn{3}{|c|}{30 DAS } & \multicolumn{3}{|c|}{60 DAS } & \multicolumn{4}{|c|}{ AT Harvest } \\
\hline & Leaves & Stem & Root & Leaves & Stem & Root & Leaves & Stem & Root & Grain \\
\hline \multicolumn{11}{|c|}{ Nitrogen $\left(\mathrm{kg} \mathrm{N} \mathrm{ha}^{-1}\right)$} \\
\hline $\mathrm{N}_{0^{-}}-0$ & 3.86 & 13.42 & 2.45 & 16.80 & 21.45 & 3.92 & 21.49 & 25.71 & 7.14 & 55.49 \\
\hline $\mathrm{N}_{1}-90$ & 4.05 & 14.56 & 2.81 & 18.18 & 23.14 & 4.43 & 24.07 & 26.61 & 8.09 & 56.85 \\
\hline $\mathrm{N}_{2}-120$ & 4.42 & 15.07 & 2.83 & 18.84 & 25.45 & 4.51 & 24.54 & 27.72 & 8.36 & 57.84 \\
\hline $\mathrm{N}_{3-}-150$ & 4.98 & 16.56 & 3.17 & 20.26 & 26.61 & 5.18 & 26.30 & 30.86 & 9.44 & 62.33 \\
\hline S.Em.土 & 0.11 & 0.29 & 0.08 & 0.53 & 0.65 & 0.13 & 0.67 & 0.74 & 0.23 & 1.22 \\
\hline C.D. at $5 \%$ & 0.32 & 0.84 & 0.24 & 1.53 & 1.87 & 0.38 & 1.93 & 2.14 & 0.67 & 3.54 \\
\hline \multicolumn{11}{|c|}{ Phosphorus $\left(\mathrm{kg} \mathrm{P}_{2} \mathrm{O}_{5} \mathrm{ha}^{-1}\right)$} \\
\hline $\mathrm{P}_{0^{-}}-0$ & 4.00 & 14.02 & 2.68 & 17.22 & 21.45 & 4.00 & 22.63 & 24.37 & 7.13 & 55.30 \\
\hline $\mathrm{P}_{1}-45$ & 4.20 & 14.93 & 2.73 & 17.70 & 23.44 & 4.44 & 23.06 & 25.05 & 7.96 & 56.15 \\
\hline $\mathrm{P}_{2}-60$ & 4.50 & 15.20 & 2.79 & 18.92 & 24.00 & 4.58 & 24.77 & 29.58 & 8.63 & 58.58 \\
\hline $\mathrm{P}_{3}-75$ & 4.61 & 15.46 & 3.03 & 20.24 & 26.35 & 5.02 & 25.94 & 31.90 & 9.30 & 62.48 \\
\hline S.Em.. & 0.11 & 0.29 & 0.08 & 0.53 & 0.65 & 0.13 & 0.67 & 0.74 & 0.23 & 1.22 \\
\hline C.D. at $5 \%$ & 0.32 & 0.84 & 0.24 & 1.53 & 1.87 & 0.38 & 1.93 & 2.14 & 0.67 & 3.54 \\
\hline \multicolumn{11}{|c|}{ NxP Interaction } \\
\hline S.Em.. & 0.22 & 0.58 & 0.17 & 1.06 & 1.29 & 0.26 & 1.33 & 1.48 & 0.47 & 2.45 \\
\hline C.D. at $5 \%$ & NS & NS & NS & NS & NS & NS & NS & NS & NS & NS \\
\hline C.V.\% & 9.11 & 6.77 & 10.44 & 9.88 & 9.28 & 10.04 & 9.60 & 9.24 & 9.80 & 7.30 \\
\hline
\end{tabular}


Fig.1 Effect of nitrogen and phosphorous on total dry weight of leaves, stem, root and grain (g plant $^{-1}$ ) at different growth stages

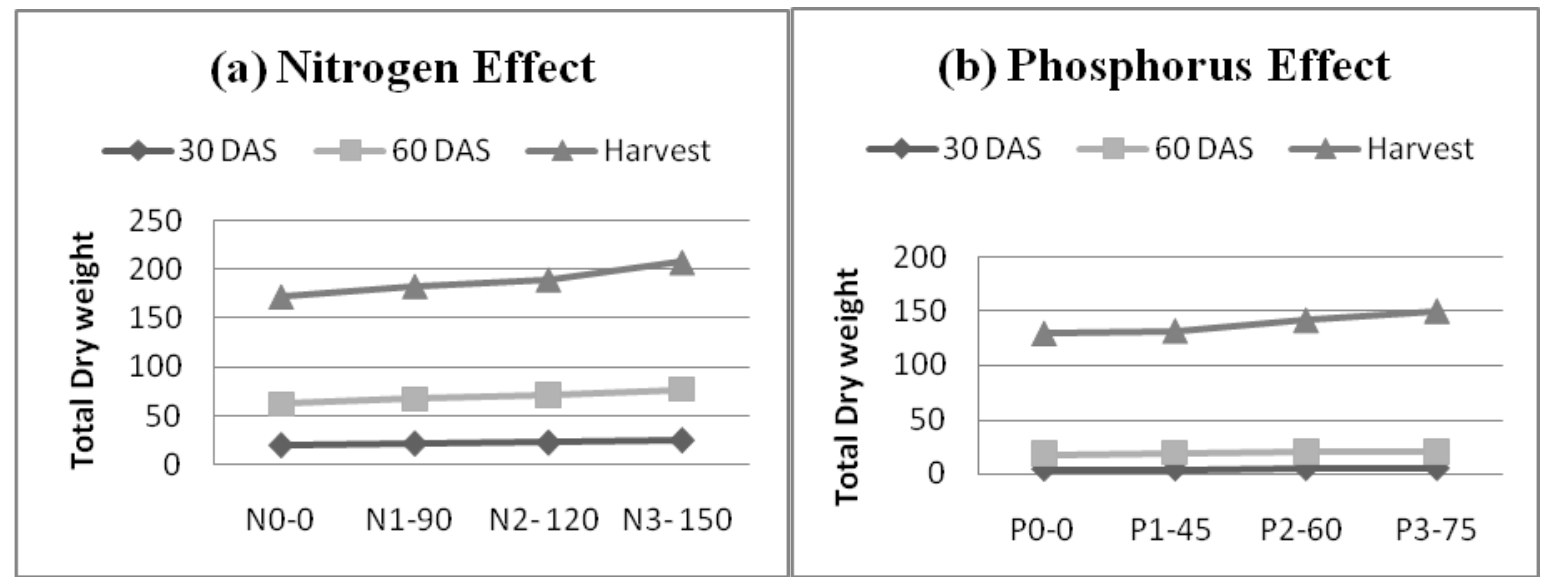

The application of phosphorus@75 kg ha ${ }^{-1}$ $\left(\mathrm{P}_{3}\right)$ gave significantly higher dry weight of leaves $\left(25.94 \mathrm{~g} \mathrm{plant}^{-1}\right)$, stem $\left(31.90 \mathrm{~g} \mathrm{plant}^{-1}\right)$, root $\left(9.30 \mathrm{~g} \mathrm{plant}^{-1}\right)$, grain $\left(62.48 \mathrm{~g} \mathrm{plant}^{-1}\right)$ and total plant $\left(129.62 \mathrm{~g} \mathrm{plant}^{-1}\right)$. It was remained at par with dry matter yield of leaves (24.77 $\left.\mathrm{g} \mathrm{plant}^{-1}\right)$ and root (8.63 $\left.\mathrm{g} \mathrm{plant}^{-1}\right)$ after harvest of popcorn. The interaction effect of nitrogen and phosphorus did not produced significant effect on dry weight of leaves, stem, root, grain and total plant of popcorn at harvest. Increased dry matter production with increased fertilizer application was due to role of $\mathrm{P}$ in determining the efficiency of sunshine by the increased biomass and any inadequacy of nitrogen reduces the sunshine use efficiency or ability to photosynthesized as reported by Wadsworth (2002). Thus greater availability of photosynthates, metabolites and nutrients to develop reproductive structures seems to have resulted in increased dry weight of vegetative parts of plants i.e., leaves, stem root and grain. Initially, leaf rather than the number is increases but the numbers of leaves are subsequently increased by sustained leaf production over a longer period. However, it was noticed that the dry mass of the leaves sample with the highest phosphorus dose of $75 \mathrm{~kg} \mathrm{P}_{2} \mathrm{O}_{5} \mathrm{ha}^{-1}$ was found significantly higher than the other lower level, similar result seen by El-Hamdi and Woodard (1995) and Lu and Miller (1993), where the increase of phosphorus dose, increased the percentage of content of nutrients, the dry matter accumulation significantly increased by maximum application of phosphorus. Banerjee et al., (2006), Arya and Singh (2011) in maize, The present findings are within the close vicinity of those reported with phosphorus by Padmaja et al., (1999), Raja (2001), Sahoo and Mahapatra (2004), Pal (2013), Babak et al., (2012), Mehta (2002), Chabi et al., (2008), Gokmen et al., (2001), Kumar (2009), Kanannavar (2013), Prathyusha and Hemalatha (2013) in popcorn.

However, the results seems quite logical to conclude that significantly the higher dry matter yield of leaf, root, stem, grain and total plant at 30DAS, 60DAS and at harvest were obtained from rabi popcorn (cv. Amber) by fertilizing the crop with nitrogen application @ $150 \mathrm{~kg} \mathrm{~N} \mathrm{ha}^{-1}\left(\mathrm{~N}_{3}\right)$ and $75 \mathrm{~kg} \mathrm{P}_{2} \mathrm{O}_{5} \mathrm{ha}^{-1}\left(\mathrm{P}_{3}\right)$ in medium black calcareous soils of Saurashtra region of Gujarat.

\section{References}

Arya, K.C. and Singh, S.N. 2001. Effect of different levels of phosphorus and Zinc on yield and nutrient uptake of maize 
(Zea mays L.) with and without irrigation. Indian J. Agron., 71: 57-59.

Babak, P., S.M. Seify., M.S. Fadaei and Abdoli, M. 2012. Impact of nitrogen fertilizer rates on growth and yield attributes of popcorn grown under different potassium levels. Int. J. Agri. Sci., 2(4): 420-424.

Banerjee, M., Rai, R.K., Srivastava, G.C., Maiti, D. and Dhar, S. 2006. Influence of nitrogen and phosphate solubilizing bacteria and phosphorus sources on growth, chlorophyll and yield of maize. Indian J. Plant Physiol., 11(4): 373378.

Chabi, O., Adenirin and Shulthess, F. 2008. Effect of nitrogen and potassium on yields and infestimation of maize by Busseolafusca in humid forest of Cameroon. J. Economic Entomol., 101(9): 90-98.

Choudhary, J. and Singh, D. 2006. Effect of plant population and fertilizer levels on yield and economic viability of popcorn. Agron. Digest, 6\&7: 14-15.

El Hamdi, K.H., Woodard, H.J. 1995. Response of early corn growth to fertilizer phosphorus rates and placement methods. J. Plant Nutri., 18(6): 1103

FAO STAT. 2014. Crop production data maize 2014.http://faostat.org.retrieved on 30 March, 2014.

Gokmen, S., Sencar, O. and Sakin, A. 2001. Response of Popcorn (Zea mays everta) to Nitrogen Rates and Plant Densities. Turket J. Agri., 25: 15-23.

Hokmalipour, S. and Darbandi, M.H. 2011. Effects of Fertilizer on chlorophyll content and other leaf Indicator in three cultivars of maize (Zea mays L.) World Appl. Sci. J., 15(12): 1780-1785.

Hokmalipour, S., R. Seyedsharifi, S.H. Jamaati-e-Somarin, M.Hassanzadeh, M.Shiri-e-Janagard and R. Zabihi-eMahmoodabad. 2010. Evaluation of Plant Density and Nitrogen Fertilizer on
Yield, Yield Components and Growth of Maize. World Appl. Sci. J., 8(9): 1157-1162.

Hussaini, M.A., Ogunlela, V.B., Ramalan, A.A and Falaki, A.M. 2001. Growth and development of maize (Zea mays L.) in response to different levels of nitrogen, phosphorus and irrigation. Crop Res. Hisar, 22(2): 141-149.

Kanannavar, R. 2013. Response of popcorn (Zea mays Var. everta) to nitrogen phosphorus and potassium levels in northern transition zone of Karnataka, M.SC Thesis 10661 Agri, Department of Agronomy, University of Agricultural Sciences, Dharwad, Karnataka.

Kumar, A. 2007. Productivity, economics and nitrogen-use efficiency of specialty corn as influenced by planting density and nitrogen fertilization. Indian J. Agron., 52(4): 306-309.

Kumar, A. 2009. Influence of varying plant population and nitrogen levels on growth, yield, economics and nitrogen use efficiency of popcorn (Zea mays evertasturt). Crop Res., 37(1, 2 \& 3): 19-23.

Marschner, H. 1995. Mineral nutrition of higher plants, Academic Press, London.

Mehta, Y.K. 2002. Effect of sulphur, phosphorus and FYM on productivity of maize (Zea mays L.) and their residual effect on mustard (Brassica javanica) Czero and Coss at varying fertility levels. Ph.D. thesis submitted by Maharana Pratap University of Agriculture and Technology, Udaipur.

NIIR. 2013. All India Area, Production and Yield of Maize along with coverage under Irrigation. NIIR Project Consultancy Services (NPCS), New Delhi. http://www.niir.org/information.

Padmaja, M., Sreelatha, D. and Rao, K.L. 1999. Effect of nitrogen on nutrient uptake in maize (Zea mays L.) types. $J$. 
Res. ANGRAU, 27: 112-114.

Pal. 2013. Response of maize (Zea mays L.)

to various levels of $\mathrm{N}$ and $\mathrm{P}$ on calcareous soils of Saurashtra, thesis M.Sc. Dept. of Agronomy, Gujarat.

Panse, V.G. and Sukhatme, P.V. 1985. Statistical Methods for Agricultural Workers. Indian Council of Agricultural Research, New Delhi.

Popcorn Board. 2015. Nutritional data for popcorn. USDA nutrient laboratory.

Prathyusha, C. and Hemalatha, S. 2013. Yield and economics of specialty corn at various levels of nitrogen application under pongamia + maize agri-silvi system, Int. J. Adv. Res., 1(6): 476-481

Prathyusha, C., Hemalatha, S., Praveen Rao, V., and Jayasree, G. 2014. nitrogen response, nutrient uptake by the crop and post harvest soil fertility status in specialty corn as influence by nitrogen fertilization under pongamia + maize agrisilvisystem. Dept. of Agronomy,
College of Agriculture, Rajendranagar, Hyderabad-500030, AP, India, Email id:prathyushareddy.162@gmail.com, (4)3: 170-173.

Sahoo, S.C. and Mahapatra, P.K. 2004. Response of sweet corn to nitrogen levels and plant population. Indian $J$. Agri. Sci., 74(6): 337-338.

Setty R.A. 1981. Aronomic investigations on irrigated rabi maize (Zea mays L) Ph. D. thesis University of Agricultural Sciences, Bangalore, India.

Verma, I.B. and Singh, S.S. 2014. Effect of nitrogen and potassium levels on growth and yield of popcorn (Zea mays evertasturt.) cv. VL Amber, The Allahabad farmer, Department of Agronomy, SHIATS, Allahabad, LXX, (1): 294-300

Wadsworth, G. 2002. Forage maize fertilizer requirement, Potash Development Association, Brixtraw, Pp. 25-29.

\section{How to cite this article:}

Shalini Kumari. 2017. Effect of Nitrogen and Phosphorus Level on Dry Matter Yield at Different Growth Stages of Popcorn in South Saurashtra Region of Gujarat, India. Int.J.Curr.Microbiol.App.Sci. 6(8): 547-553. doi: https://doi.org/10.20546/ijcmas.2017.608.071 